Article

\title{
Neoliberalism Meets "Gangnam Style": Vernacular Private Sector and Large Urban Developments in Seoul
}

\author{
Jinhee Park \\ Independent Researcher, South Korea; E-Mail: ginnypark0715@gmail.com
}

Submitted: 31 May 2019 | Accepted: 2 September 2019 | Published: 21 November 2019

\begin{abstract}
Globalised neoliberalism does not unify urbanisation processes but rather varies according to local contexts. This article explores the unique neoliberalisation process in large urban developments that have contributed to Seoul becoming a global city. Not only has the formal process of privatisation been important but also the vernacular practice of the ordinary people has informally grown during the process. By establishing a matured market of the mass production and consumption of high-rise apartments since the 1970s, more than half of the housing stock is now composed of high-rise apartments in South Korea. Gangnam represents the wealthiest district shifting from rural sites to highly dense urban areas due to their large-scale high-rise developments. Not only have societal changes made way for super-high-density apartment complexes as a rational response to population and economic growth, high-rise developments have also allowed Seoul to grow its population and expand its spatial footprint. Because of the dominance of universal western knowledge, this phenomenon has not been fully understood. While neoliberalism has been broadly adopted, the actual development process in Korea is distinctive not only from the West but also the East. The article argues that 'vernacular neoliberalism' has evolved not just by the formality of the ideological market system but also by the informality of survival practices of Korean lives largely under the colonial period and the aftermath of the Korean War. It particularly shows how large urban developments have been widespread by integrating a vernacular private rental system called chonsei into the formal structure.
\end{abstract}

\section{Keywords}

Asian cities; chonsei; housing policy; Korea; neoliberalism; Seoul; urban redevelopment

\section{Issue}

This article is part of the issue "Large Urban Developments and the Future of Cities" edited by Efrat Eizenberg (TechnionIsrael Institute of Technology, Israel).

(C) 2019 by the author; licensee Cogitatio (Lisbon, Portugal). This article is licensed under a Creative Commons Attribution 4.0 International License (CC BY).

\section{Introduction}

In 2012 a music video called Gangnam Style by the Korean musician Psy parodied an image of middleclass lifestyles in Seoul that centre on life within highrise apartment complexes in the city's Gangnam district. Despite its wide popularity once over the world, few would know the true meaning of Gangnam Style. Without a doubt, South Korea is one of the world's fastest-growing economies, having increased from one of the world's poorest countries with less than US $\$ 100$ GDP per capita in 1960 to the world's 12th largest economy in 2018 recorded by the IMF. Accordingly, its economic geography ranked in the beta world cities in 1998 and was upgraded to alpha world cities in 2018 according to the inventory of alpha, beta and gamma world cities assessed by the Globalization and World Cities Study Group and Network (GaWC). This shows how globalised Korea has become and how a global city Seoul is by the international standard. However, how it has been achieved is not yet fully understood. Whilst Gangnam style was a popular phrase throughout the rest of the world, not many people may have had the knowledge that Gangnam is the wealthiest district consisting of large-scale high-rise developments in Seoul, established by the process of modernisation and globalisation from the 1970s in Korea. In short, according to Robinson (2006), Seoul is on the map, but off the theory. 
Large urban projects have now become a widespread development pattern within developing countries so that they can be included in globalised economic networks (Roy, 2009, 2011). Peripheries of the cities become eminent for such projects to be developed by the private sector-led entrepreneurialism, attracting a global flow of finance and ideas (Percival \& Waley, 2012; Shatkin, 2008). They are thus seen as a distinctive form from previous urban developments, mostly described by rather small numbers of Western cities like Paris, London, and New York, which contrasts between 'mega-cities' of the Third World and implicates them as problems and 'global cities' of the First World cities as models (Roy, 2009). Whilst this phenomenon of large urban developments has recently attracted academic interests, Korea was an early developing country having grown from being a Third World to a First World country in a short space of time and with its large urban projects being produced to solve urban problems and to grow the national economy under dominant western knowledge. Although Seoul has resulted in being listed on the map of global cities, how it achieved its status differently from other First World cities is less known. Instead, the view that a large-scale of high-rise developments is an abnormal phenomenon pertaining to Korean society is more common.

Not only have societal changes made way for largescale high-rise developments as a rational response to population growth, high-rise apartments have also allowed Seoul to grow and expand its spatial footprint. Following the transformation of social contexts forced by external pressures especially by the colonisation by Japan (1910-1945) and the Korean War (1950-1953), their effects on the urban situation brought a contingent and somewhat inevitable outcome of a privatised market structure over the 20th century. This was due to both the indifference of the colonial government towards the Korean population and the incapacity of an unprepared government to respond to them after the independence in 1945 and the following Korean War. Given the circumstances, large-scale urban developments based on high-rise residential buildings as a mix of commercial, public service, residential and recreational space were seen as time and cost effective to respond to the rapid urbanisation by the Korean government in the 1960s. This was brought by combining the modernist ideology of standardised quality and mass production based on modern technology by Le Corbusier (1960) and the concept of the neighbourhood unit as a self-contained community conceived by Perry (1929). Since then, they were proliferated throughout the country by involving large construction companies called chaebols (Korean multinational conglomerates, such as Hyundai, Samsung, Daewoo and LG). There is no doubt that such large-scale urban projects have contributed to the economic growth of the country in which the residential construction industry increased up to $68.1 \%$ out of the whole construction industry in the 1990s (Lee, 2007).
Recently, the Korean model has been more commonly imported to other nations as it is perceived as being ideal not just as an urban model but also as an economic model for developing countries such as Vietnam, Cambodia in South-East Asia and increasingly extending to cities in CIS, Middle East, Africa, or Latin America going through serious housing shortages or slums (Lee, 2014). With the accumulated expertise and construction techniques to build high-rise buildings and to design large urban projects through Korea's rapid urbanisation process, most large-scale developments are predominantly composed of high-rise residential buildings in these overseas developments (Paling, 2012; Percival \& Waley, 2012). Recent events, such as the MOU agreement between the Korean government and the World Bank in 2015 to support building new towns and infrastructure in developing countries, and the naming of a road within a new town as 'Avenida Corea' in Bolivia symbolising the cooperation and friendship between the two nations in 2017 are examples of such intended outcomes. While there exists a number of challenges such as lack of global acknowledgement, network or funds, these efforts show that Seoul is aiming to firmly secure its status of being recognised as a global city (The Seoul Institute, 2014).

As Robinson (2002) noted, nevertheless, "the complex inter-referencing of models across Asia may be related to 'Western' urban theories, but they are not defined by them." However contradictory or complementary they may be, Euro-American perspectives have not grasped the understandings of other worlds; particularly the earlier developing countries such as the 'Four Asian Tigers' and also other emerging countries like China and India (Featherstone \& Venn, 2006). How and why did large-scale urban projects become pivotal to urban solutions and economic growth for Korean governmental policy? How did private developers as providers coupled with residents as consumers indulge in shaping the market of high-rise developments in Korea unlike other cities rather based on low-rise suburbanisation processes in the West? Hence, global city rankings that are ascertained by Western standards cannot account for differences of developments across other world cities (Friedman, 1995). It is because the approach tends to ignore the lived experience such as struggle or resistance that can be understood as a 'clash of rationalities' between formal marketised systems and informal conditions (Watson, 2009). In this sense, the article argues that 'vernacular neoliberalism' has evolved not just by the formality of an ideological market system but also by the informality of survival practices of Korean lives largely under the colonial period and the aftermath of the Korean War. It shows how a vernacular private rental system called chonsei has been integrated into the formal structure of large urban developments. Therefore, the research is mostly based on a documentary approach with complementary secondary data to understand the historical process of development. 


\section{Variegated East-Asian Neoliberalism in Large-Scale Urban Development}

Through globalisation processes, a new ideological paradigm of neoliberalism accelerated in the 1980s crossed over multiple geographical and sociological conditions (Park, Hill, \& Saito, 2012). By the winning ideology of neoliberalism, urban governance has shifted from managerialism in the 1960 s to entrepreneurialism in the 1970 s and 1980s, which has brought about a general shift in attitudes towards housing provision away from public concerns to private acquisition over the last decades (Forrest, 2003; Harvey, 1989). Such an entrepreneurial approach towards the private-led growth becomes more apparent particularly due to the outcomes of Asian developmentalism since the global financial crisis (Cammack, 2012). Because capitalism is adapted to a heterogeneous global world with a so-called 'variegated capitalism' (Peck \& Theodore, 2007), there are therefore some important local differences within the broad neoliberal landscape.

Early developed countries, such as those in northern Europe, had established the welfare state to reconstruct society from the aftermath of the World Wars in the beginning of the 20th century, which was based on Keynesian managerialism (Park et al., 2012). Within this, housing was largely provided by the state in which it was generally considered as a public responsibility rather than a market product. However, given the lack of public resources and its concomitant economic recession, the strong regulated turn towards the market-oriented housing system based on home-ownership ideology has swept through countries (Forrest, 2003). Compared to the Western world, in Eastern countries developmental ideology has been particularly concerned in 'catching up' with already-developed countries, replacing public welfare services with the aim of economic growth (Holliday, 2000; Park et al., 2012). In the development of these countries, housing has been particularly important not just in terms of a duty to distribute opportunity but more as a trigger of the nation's economic development (Lee, Lee, \& Yim, 2003).

Due to such different traces, whilst recognising the 'failure' of high-rise living in the West in the mid-20th century until recent regeneration projects based on sustainable development in many parts of the earlier developed western world (Baxter \& Lees, 2009; Colomb, 2007), there is a contrasting situation in the East, where large-scale development of high-rise housing has been largely adopted along with the developmental engine of economic growth (Forrest, Lee, \& Wah, 2000). Despite similar tendencies of direct state provision, the universal home-ownership model in Singapore was based on a 99-year lease with state land ownership whilst Hong Kong's regime of property-led accumulation and its hegemonic urban redevelopment may have led to high speculation tendency and widened social inequalities with a much slower home ownership program (Huat, 2003; Lee et al., 2003; Tang, 2017; Wah, 2000). On the other hand, Japan, Taiwan and South Korea have much more limited state provision of housing being largely dependent on private developers in line with economic development (Chen \& Li, 2012; Lee et al., 2003). In both sectors of public and private provisions since the 1970s, Korea started with mostly private ownership and then shifted focus towards social welfare, following the Asian and global economic crises (Ha, 2010; Ronald \& Lee, 2012). Unlike Korea, in Japan (and Tokyo in particular), the change in high-rise ownership from public to private may have come from new policy practices of encouraging construction of high-rise condominiums from the 1990s after the collapse of the country's economic bubble (Hirayama, 2005; Ronald \& Hirayama, 2006). Hence, there has not been universal convergence with no clear distinction between public or private, ownership ratio and household affluence (Lee et al., 2003), although policies across the world have generally taken a direction towards the market production and consumption of housing. This may be because "economic globalisation does not alter urban cultures in deterministic ways, as cities are nested in different national, social and cultural contexts from which emerge different strategies for the management of or resistance to globalisation" (Clammer, 2003, p. 404).

As such, 'process' rather than 'trait' geographies are more likely to produce dynamic knowledge beyond Euro-American hegemony of urban theory (Roy, 2009). Actually existing urbanisms involve the complexity in global and local juncture via experiencing social dynamics such as informality, resistance, which is much less known in dominant theorisations of global city-regions on the map (Roy, 2009; Shatkin, 2011). Because the diffusion process in globalisation is never direct or oneway and instead imported ideas are re-formed to adapt to the local contexts through variation and contestation, the formal planning process rationalised for technomanagerial and marketised system confronts the other end of rationality by the informality of the survival from hardship (Watson, 2009). Moreover, rapid and unpredictable growth relies more on such informality rather than the established power (Watson, 2009). In this sense, the current system of large urban developments in Korea cannot be fully understood without understanding social conditions inherited from the historical contexts. In particular, vernacular institutions have grown to survive during the harsh time over the external and internal power, which became informally integrated into the dominant market structure and has played a crucial role in large urban developments. Here, 'vernacular neoliberalism' can be seen as a process integrating the informal privatisation (chonsei) to formal marketised privatisation (ownership). As such, the concept of 'vernacular neoliberalism' can be defined as a form of variegated neoliberalism that although it is basically operated by privatised activities to provide public services (e.g., housing) within the free market system of neoliberalism, instead of fully evolving out of formal institutions it is however com- 
plimented by ordinary people developing an informal system through everyday practices. That is, it can be characterised as practical, informal or indigenous, nonprofessional or elite, which can be effectively vulnerable by its insecure status. Because of such vulnerability, there have been attempts to protect tenants (the special civil law of tenancy protection) or to integrate the chonsei system in to a formal system (chonsei loan, governmental long-term chonsei) by the Korean government since the beginning of the 1980 s when it became apparent that landlords were manipulating the system, leaving tenants with housing insecurity and it becoming a serious social issue (note that this discussion is not further explored for this article).

\section{The Historical Housing Shortage in Korea}

Since the Ganghwa treaty forced by Japan in 1876 , the tremendous changes from the closed and fixed Korean society under the Confucianism in Choson society were seen in the physical transformation of traditional urban areas (Jeon, Son, Yang, \& Hong, 2008). The extension of urban areas was led by the population growth in Seoul due to a new social order and populated by Japanese settlers at the end of the 19th century (Jeon et al., 2008). During the Choson dynasties spanning over 500 years from 1392 to 1910, the growth of the population was not significant, and the administrative boundary of the city continued without major differences (Cha, You, \& Lee,
2004). Although Seoul was characterised by a relatively high density in its urban parts, with 100,000 people in $16.5 \mathrm{~km}^{2}$ within the walls (approximately 60 persons per hectare), but only 10,000 people in outer walls in 1428 , the population of Seoul remained at around 200,000 since the mid-17th Century for 200 years (Cha et al., 2004). While this figure represents a big size of urban population for a pre-industrialised society, housing shortage was not a big problem for over 500 years as the ratio of a house per household was roughly 1 to 1 (Son, 1986). This remained steady until the 1920s with little growth of the population at $0.8 \%$ in Seoul, even though other local cities had more significant growths (Son, 1986). Since the 1920s after the independence movement in 1919, the population increased sharply in Seoul, especially out of the central urban area because of central Japanese occupation (Son, 1996a). It reached up to around 730,000 in 1936 and 900,000 in 1945 compared to 250,000 in 1910 when Korea was annexed to Japan, largely due to changes in socio-economic structure leading farmers to move into urban areas (Cha et al., 2004). There was thus an inevitable result that the issue of housing shortage came to the fore during these periods.

Table 1 shows that, as the population went up increasingly since 1919 , the shortage of housing became significant at $5.77 \%$ in 1926 and doubled to $10.62 \%$ five years later in 1931 . With continuous increases, the shortage of housing stock was around $10-15 \%$ through the beginning of the 1930s and became worse at over

Table 1. Housing shortages (Seoul) in the Japanese colonial period. Data extracted from Kim (2010) and Son (1996b).

\begin{tabular}{|c|c|c|c|c|}
\hline Year & Households & Housing stock (units) & Housing supply (\%) & Housing shortage (\%) \\
\hline 1925 & - & - & 95.55 & 4.45 \\
\hline 1926 & 68,862 & 64,889 & 94.23 & 5.77 \\
\hline 1931 & 77,701 & 69,453 & 89.38 & 10.62 \\
\hline 1932 & 78,261 & 57,965 & 74.06 & 25.94 \\
\hline 1933 & 79,519 & 70,599 & 88.78 & 11.22 \\
\hline 1934 & 80,961 & 68,186 & 84.22 & 15.78 \\
\hline 1935 & 131,239 & 101,767 & 77.54 & 22.46 \\
\hline 1936 & 138,583 & 107,946 & 77.89 & 22.11 \\
\hline 1938 & 148,856 & - & - & - \\
\hline 1944 & 220,938 & 132,000 & 59.75 & 40.25 \\
\hline 1961 & 485,129 & 275,436 & 56.78 & 43.22 \\
\hline 1962 & 554,136 & 306,289 & 55.27 & 44.73 \\
\hline 1963 & 597,132 & 322,386 & 53.99 & 46.01 \\
\hline 1964 & 633,026 & 331,133 & 52.31 & 47.69 \\
\hline 1965 & 649,290 & 345,657 & 53.24 & 46.76 \\
\hline 1966 & 724,043 & 361,943 & 49.99 & 50.01 \\
\hline 1967 & 754,261 & 406,119 & 53.84 & 46.16 \\
\hline 1968 & 837,362 & 506,810 & 60.52 & 39.48 \\
\hline 1969 & 961,491 & 543,645 & 56.54 & 43.46 \\
\hline 1970 & $1,029,000$ & 584,000 & 56.75 & 43.25 \\
\hline 1980 & $1,724,000$ & 968,000 & 56.15 & 43.85 \\
\hline 1990 & $2,518,000$ & $1,458,000$ & 57.90 & 42.10 \\
\hline 2000 & $2,548,000$ & $1,973,000$ & 77.43 & 22.57 \\
\hline 2010 & $2,610,400$ & $2,525,210$ & 96.74 & 3.26 \\
\hline
\end{tabular}


$20 \%$ since the mid-1930s. Surprisingly, in 1944 , its figure reached $40.25 \%$, as housing stock increased only just over twofold but households increased more than three times compared to 1926. However, Son (1986) emphasises that the problem of housing shortages was only of concern to the middle classes at the time of the colonial government, and these figures thus include only them, not lower classes or squatters for whom the problem was doubtlessly worse. As such, the housing shortage reflected the severe housing condition of those that could not secure their own housing and were prone to rent a part of a house let by its landlord with extremes of a single room for a family of 5-8 members, whilst those who even could not afford partial renting built informal shelters in the peripheries of the city (Jeon et al., 2008). During the 1920 s to 1930 s, while the residential settlements for higher classes were thus expanded around and out of the city centre in Seoul, which was encouraged due to the land development by private industries, the informal settlements of squatters also increased significantly (Cha et al., 2004; Yang, 1991). Given the context of the colonial period that was interested in exploitation rather than the welfare of Korean citizens, it seems that the problem of urban housing was broadly left to private solutions, and poor housing was not considered generally a central issue.

To make matters worse, it is estimated that $50 \%$ of Seoul housing stock was damaged by the following Korean War, being the most attacked area and approximately $30 \%$ of the whole stock was to be rebuilt due to its complete destruction (Kim, 2001). The housing shortage was yet to be severe though, because most citizens were evacuated to other provinces during the war until the armistice agreement in 1953. Soon after, however, the population increased greatly due to a variety of factors such as returning citizens and rural exodus, which led to the extended areas of illegal buildings and slums in addition to the previous poor settlements since the 1920s. Consequently, the housing shortage continued to increase up to $50 \%$ in the mid-1960s when it was the worst due to the explosive population growth with rural exodus in the poor conditions of the economy (Kim, 2010). Even though the government started to construct housing with assistance from international aid right after the ceasefire of the war, it was very limited to meeting the needs of housing shortage but rather triggered the encouragement of private supply (Kim, 2001). These series of historical housing shortage and poor conditions may have become an inevitable vehicle of privatisation of housing in Korea, which is not so much based on the ideological underpinning, but instead a competition of survival.

\section{Privatisation of Urban Housing}

\subsection{Construction of Private Housing Industries}

The public ownership of land that was not limited to construct houses in Choson society also faced privati- sation as Japanese settlers insisted on ownership of land on which they bought a house in 1909 (Jeon et al., 2008). The colonial government commenced the Land Readjustment Scheme (LRS) in 1937 following the Choson Urban District Planning Act (CUDPA) in 1934 in order to accommodate the increased population, to manage the urban growth, and to make effective administration (Cha et al., 2004) by improving their use value and to regulate development on empty land (Lee, 1986). However, in 10 districts designated by the scheme before 1945 , they were spatially separated broadly in two forms in which one was comprised of Japanese residential settlements based on industrial areas, and the other was simply housing sites for Koreans to solve housing shortages in urban areas (Song, 1990). Even though the colonial government managed the process of development and the land supply of housing construction, the actual provision of housing predominantly relied on private development because housing shortages only affected Koreans, not Japanese (Son, 1986).

Through the difficulty of the housing shortage there was a change in housing perspectives in that housing came to have a meaning as an asset, which led to the growth of the house-building companies and housing lease businesses (Park \& Jeon, 2002). Whilst private developers were actively involved in the construction of housing within the walls of Seoul from the 1920s, they were spread to outer areas of the walls with mass provision since the LRS in 1937 (Jeon et al., 2008). The private housing market was thus naturally structured from the beginning of the 1920s and dramatically increased in the 1930s in which houses were built by private developers, and largely consumed by those who were to sell or to let them, which were mediated by leasing companies (Park \& Jeon, 2002). Whilst many of them were sold to those who were the rich landowners in local areas and who moved to Seoul, a large portion of new houses was also consumed by letting to students who came from local regions or poor classes (Park \& Jeon, 2002). Eventually, it can be said that the privatised ownership was important for the higher class, whereas the private rental market of chonsei was the important and probably only method for the lower class to survive under the colonial government with indifference toward Korean lives.

\subsection{Vernacular Private-Renting System (Chonsei)}

The private renting system called chonsei evolved from the modern historical contexts by external forces from the Japanese colonial period and the Korean War described above, which is a unique method for South Korea. Whereas monthly rent is common all over the world in contexts such as industrialised urban areas due to a variety of factors including the population growth and consequent housing shortage during the urbanisation, it was rarely adopted for housing rather than commercial property until the mid-20th century in Korea according to the survey report of the Choson customs by the 
colonial government in 1910 (cited in Choi \& Ji, 2007). While the origin of chonsei is not exactly known with little written records, the report recorded it as the most general housing rental method that tenants pay a lump-sum deposit of between $50 \%$ and $70-80 \%$ of the property value for a fixed period of tenancy, instead of monthly rent, and the deposit is reimbursed at the end of the contract (Choi \& Ji, 2007). Whether chonsei originated before or from Choson society is considered as a matter of controversial debate. Nevertheless, it is suggested that the chonsei renting system emerged spontaneously over time through individual transactions due to the increase of population who moved away from rural areas to Seoul in the process of constructing Japanese settlements since the Ganghwa forced treaty opening three ports in 1876 (Park, 2000). Although the colonial government somewhat weakened it to limit tenant rights, it continued to proliferate and was recorded as the most prevalent pattern of renting housing according to the 1944 survey report of the chonsei custom (Park, 2000). Furthermore, it was widespread from Seoul to other areas as well throughout the rapid urbanisation and its housing shortage after the Korean War (Kwak, 1966, as cited in Choi \& Ji, 2007).

Despite the controversy between the pros and cons of this informal renting system, it is widely recognised that the chonsei transaction is based on mutual benefit between landlords and tenants in Korea. Firstly, it can be an informal financial source for landlords. Those who need a large lump-sum of money can procure it easily by letting their own properties without any formal procedures, while the chonsei deposit could be regarded as identification when letting to strangers (Park, 2000). Because of a relatively large sum of the deposit, it can be used to attain multi-buy housing. On the other hand, a chonsei deposit can be a secure saving of their assets for tenants until achieving ownership compared to high risk of a private loan or low interest of a formal banking scheme (Lee, 1985, as cited in Park, 2000). Also, Ambrose and Kim (2003) argued that chonsei could provide better housing than the one that can be bought by immediate cash purchase. That is, whereas landlords can benefit from the increase of housing price and the lessened risk from inflation, tenants can reduce the risk to lose the deposit and be more secure without paying high monthly rent (Cho, 1988). Therefore, the next section explores how it has played a significant role in the current large urban developments in Korea.

\subsection{Passing the Baton to the Private Sector in Gangnam's Large-Scale Urban Development}

During the reconstruction of the country especially from the aftermath of the Korean War following a weakened Korean government after a long colonial period, the country's economic reorientation into an exportoriented structure included the aim of replacing a public housing solution with macro-economic growth so as to increase households' income that enables consumers to purchase their own housing in the private market (Lim, 2005). This was because the government's efforts to improve urban squatter areas and the housing shortage by introducing apartments were unsuccessful during the 1950-1960s. The provision of mostly small apartments achieved through national public funds and foreign aid finance was for lower-income households, whereas middle- and high-class households preferred detached houses until the 1960s (Gelézeau, 2007). To make matters worse, the negative perception against high-rise buildings came from the accidental collapse of the Wawoo apartment complex just three months after completion in 1970, which resulted in 34 deaths and 40 injuries.

Whereas the incident caused the end of the provision of such redevelopments by the demolition of existing settlements and forcibly relocating evictees to outside areas of Seoul, however, it became a motive of breakthrough that the aim of apartment policy was diverted into middle-class housing (Lee, 1995). Seung-up Lim, who was the chief of the Korea Housing Research Institute at the time, rationalised the initiative to attract private funding for middle-classes based on the realisation of the limits of the governmental support:

A number of apartments have been built with public funds, but it inevitably resulted in poor condition for lower classes as the nature of public funds....It would be the effect of killing two birds with one stone, on the one hand, to solve housing shortage, on the other hand, to relieve the public financial burden of the government if apartments could be supplied for middleclasses without the support. (Lim, 1970, pp. 58-59)

In 1971, therefore, two successful developments targeting the wealthier classes in Yeoido and Dongbu-ichondong constructed by the government turned such dislike into a positive attitude, which came to be successful without any public funds, and acted as a pioneering model for the 'Gangnam development' onward (Gelézeau, 2007; Son, 2003).

In order to boost large urban developments, the reinforcement of housing policies came throughout the 1970s. By the 10-Year Plan for Housing Construction to provide 2.5 million units of housing in 1972, a series of laws were enacted to make large urban highrise developments more flexible through the Housing Construction Acceleration Act (HCAA) in 1972, the designation of apartment districts in Gangnam under the urban planning law in 1976 and the Land Development Acceleration Act in 1980. To do so, 'high-rise apartments' were defined as residential collective buildings with over six floors and more than 20 households by architectural law, which was a typical development pattern throughout the 1980-1990s. This is in comparison to 'low-rise apartments' with five floors which mostly comprised of earlier developments in the 1970s and 'super high-rise 
apartments' that are greater than 60 metres (approximately 21-23 floors) which developed more towards the end of the 1990s that applies different architectural laws and planning policies in terms of design, structure and facilities (e.g., number of elevators, earthquake-proofing, concrete or steel, sprinklers, etc.; Land and Housing Institute, 1990). By altering the HCAA in 1977 and 1978, the policy of designated companies (mostly applying to chaebols) aimed to achieve the goal of mass production and to bring the large builders' capital into urban housing markets, which have a legal priority to construct large urban projects and benefited from financial support based on pre-sales of apartments (Ryu, 2004). This was to distinguish from registered builders (of which there are over 7,000) who can provide over 20 units annually and smaller-sized non-registered builders who are restricted to building fewer than 20 units per annum according to their size, output, and capability. Alongside the presale policy, the Housing Saving Scheme (HSS) in 1977 enabled those with savings accounts to have priority allocations for new apartments at below-market prices before they were built $(\mathrm{Ha}, 2006)$. Because of the pre-sale, the instalments paid during the construction period effectively became an interest-free fund for large builders. Furthermore, loans made from the saving scheme were given to large designated construction companies at low rates of interest by the government (Ryu, 2004).

Since the HCAA in 1972, therefore, mass-production targeting the middle classes started with a series of new neighbourhoods in Gangnam (Figure 1). This was intended to alleviate overpopulation in Gangbuk, the traditionally settled area of the city. Starting with the Banpo complex in 1973-1978, a continuous sequence of apartment blocks were developed in Gangnam. Above all, the most significant milestone of the Gangnam development was the shift from public to private towards largescale housing provision. The Apgujung-Hyundai complex (no. 5 in Figure 1) was the first apartment complex in which a private company was involved in constructing ur- ban middle-class high-rise housing (Kim \& Choe, 1997). Since then, private developments (in italics in Figure 1) came to become proliferated in Gangnam development of the 1970s that had made Gangnam a special region. In socio-economic terms, therefore, the meaning of Gangnam (grey area in Figure 1) points out the area where large urban high-rise developments were lined along the south of Hangang, whilst the literal meaning is the south of Hangang river contrary to Gangbuk (the north of Hangang). As a result, Gangnam, originally located in rural areas outside of the city, came to be a representative of the richest residential settlements in Korea, and a trigger of widespread apartment developments and extension of the city afterwards.

However, without the contribution of funding from chonsei deposits, the proliferation of large urban highrise developments would not have been widespread. Those who can afford with saving accounts of the HSS are eligible to buy new provision of apartments and become owners or possible to own multiple units with chonsei tenants. On the other hand, chonsei tenancy could be a way of resolving housing needs for those who are not eligible for purchase schemes. In addition to the weak public financial system, public provision of housing has been very limited and the majority has been for sale in which long-term public rental housing comprises only $2.3 \%$ of total housing stocks in 1999 ( $\mathrm{Ha}, 2006)$. Accordingly, the vernacular system of chonsei has continued and in fact, it has been increasingly dispersed by time and space during the mass provision of the large urban developments since the 1980s after the initial Gangnam developments.

As shown in Table 2, the chonsei ratio continuously increased from $13.05 \%$ to $55.1 \%$ in comparison to ownership ratio which fell from $82.82 \%$ to $41.2 \%$ while the rate of housing supply dramatically rose from $56.15 \%$ to 96.74\% between 1980 and 2010 in Seoul. That is to say, greater housing supply does not correlate to greater ownership. Its figure in Gangnam is even higher at $17.57 \%$ in 1980 increased to $58.51 \%$ with the very low ownership

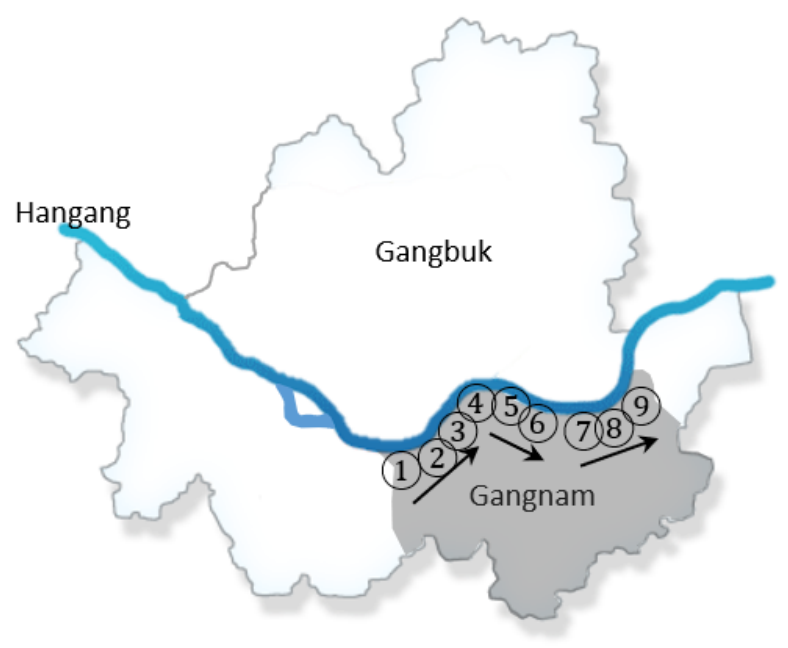

\author{
Banpo (1973-78) \\ Hanshin (1978) \\ Gyungnam (1978) \\ Hanshin (1983) \\ Hyundai (1975-82) \\ Hanyang (1977-84) \\ Chamsil (1975-78) \\ Jangmi ( 1979) \\ Siyoung (1976)
}

Figure 1. The Gangnam developments of apartments in the 1970s. Adapted from Gelézeau (2007). 
Table 2. Housing tenure ratio.

\begin{tabular}{lllccccc}
\hline & & \multicolumn{3}{c}{ Total (\%) } & & \multicolumn{3}{c}{ Apartment (\%) } \\
\hline Year & Region & Owned & Chonsei & Monthly rent & Owned & Chonsei & Monthly rent \\
\hline 1980 & Nation & 86.89 & 8.28 & 2.70 & 68.21 & 22.61 & 3.51 \\
& Seoul & 82.82 & 13.05 & 3.02 & 75.66 & 21.09 & 1.31 \\
& Gangnam & 80.48 & 17.57 & 1.28 & 78.46 & 20.11 & 0.92 \\
1985 & Nation & 83.82 & 10.91 & 1.87 & 68.76 & 24.93 & 0.96 \\
& Seoul & 80.51 & 17.32 & 0.52 & 74.16 & 23.36 & 0.52 \\
1990 & Gangnam & 76.30 & 22.01 & 0.71 & 73.61 & 25.05 & 0.75 \\
& Nation & 78.96 & 15.39 & 2.34 & 66.08 & 28.53 & 0.95 \\
& Seoul & 74.66 & 22.13 & 2.07 & 69.49 & 27.97 & 1.26 \\
& Gangnam & 72.60 & 24.48 & 1.92 & 71.21 & 26.16 & 1.80 \\
& Nation & 74.89 & 21.42 & 1.08 & 64.56 & 32.27 & 0.35 \\
& Seoul & 69.57 & 29.21 & 0.36 & 61.03 & 38.06 & 0.18 \\
& Gangnam & 64.26 & 34.69 & 0.35 & 62.39 & 36.83 & 0.31 \\
& Nation & 70.58 & 25.30 & 1.35 & 61.91 & 35.09 & 0.44 \\
& Seoul & 65.70 & 32.55 & 0.49 & 58.88 & 39.72 & 0.23 \\
& Gangnam & 59.53 & 38.68 & 0.45 & 56.75 & 41.55 & 0.40
\end{tabular}

Notes: Data from Statistics Korea (KOSIS). Chonsei data includes the partial chonsei with monthly rent for the rest of deposit.

ratio of $38.19 \%$ in 2010 . Moreover, in apartments, chonsei consisted of more than a fifth in 1980 and increased to $41.55 \%$ in 2000 in Gangnam districts. The apartment price ratio of chonsei to ownership for Seoul and nationally was recorded at $47.9 \%$ and $50.8 \%$ respectively in December 1998, and increased to $70.7 \%$ and $75.3 \%$ in December 2017. In Gangnam, it was recorded at $62.6 \%$ in December 2017. This means that a large portion of highrise construction was actually financed by chonsei deposit. Meanwhile, monthly rent without any lump-sum deposit is insignificant throughout the given period.

As a result, the number of housing stock increased almost thirteenfold from 260,000 in 1960 to 3,379,773 in 2010 , relieving the housing shortage as reached around $97 \%$ of housing supply in Seoul. By replacing detached houses with apartments, this has led to the reconfiguration of the total housing stock where $4 \%$ of the stock was apartments and $85 \%$ was detached-houses in 1970, to the situation where apartments exceeded $60 \%$ of the stock and detached-houses (except multi-households) were less than $16 \%$ in 2016 . Due to a change of preference towards apartments since the 1980s, while the transformation from single-household detached houses to dense multi-households housing (less than 4 floors and $660 \mathrm{~m}^{2}$ of total floor areas) has largely been accredited towards lower class housing, reaching around 30\% of housing stock in 2000 in Seoul (Jeon et al., 2008), such transformative activities have been manipulated in the redevelopment process so multi-holders possess the rights for multiple apartment allocation. Also, earlier developed low- and high-rise apartments are being reconstructed to super high-rise complexes in which density becomes higher by increasing the building height in or- der to increase business profits and to alleviate the fees for residents to pay for their increased unit size and construction costs. As the redevelopment or reconstruction process can take between 10 to $20+$ years, chonsei for older apartments are set up at much lower prices compared to newer constructions. For instance, examining the first Gangnam development of Banpo apartments that comprised of three complexes, the 2 nd and 3 rd complexes were reconstructed in 2009 and their price ratio of chonsei to ownership is $47 \%$ and $55 \%$ respectively by the actual transaction record of the second quarter of 2019 by the Ministry of Land Infrastructure and Transport. On the other hand, this record shows that whilst being in the process of reconstruction, the 1st complex of Banpo is only $7 \%$ and Apgujung-Hyundai is $27 \%$ in their chonsei price ratio. This wide gap attracts a variety of demands, for example, those who could afford to buy in other areas but prefer to rent in new apartments or those who cannot afford to rent new apartments but could rent for old ones in order to enjoy lifestyles or to benefit their children's education in Gangnam.

Therefore, turning back to the beginning, not only is the formal system important but also the informal system of vernacular chonsei has been a crucial factor for Seoul to become a global city and for the globalised Gangnam style according to the figures of the ratio between ownership and chonsei: chonsei was more than a third in 1995 whilst Seoul became a beta global city in 1998 index; more than a half in 2010 whilst Seoul included in an alpha global city in 2018 index. To brief, privatised large urban high-rise developments in Korea has been constructed by combining the neoliberal approach with the middle-class ownership and vernacular 
approach with lower income chonsei system together, which contributed to worlding the city Seoul. Hence, the Gangnam style is not just about middle-class lifestyle but also represents the wider groups of the population.

\section{Conclusion}

The article explored how large urban high-rise developments have been widespread by not only the formality of the marketised system but also the informality of the vernacular chonsei system. Evolving from the rapid urbanisation and its consequent housing shortage by external forces from the Japanese colonisation of Korea and the Korean War, the chonsei system has survived for more than a century extending even into the fully developed system with formal financial system and the saturated housing supply. Even though the global ideology of neoliberalism has predominated in the development framework, the vernacular chonsei system has played a crucial role by being informally adapted to the formal structure of large urban developments. This shows how globalised neoliberalism can be variegated in local contexts according to social, cultural and historical conditions in which ordinary Koreans practised the chonsei system spontaneously to survive under harsh living environments. Under the rather forced privatisation process of housing, they found a compromising way through individual transactions due to the formal housing system being out of reach for the lower classes. This vernacular practice of a private renting system is clearly distinctive from not only the West but also the East in that it could contribute differently to the economic growth of a country as well as towards individuals. In other words, the urban development and its influence on the economy and housing conditions could have arisen in alternative ways if the chonsei system had not evolved. Although there is no definitive answer to say whether it is a superior system or not, its endurance could mean that it deserves greater global recognition. However, given the dominance of the monthly rent system that is widely adopted in the West, the chonsei system is hardly recognised over the world. This led to a controversy that some policy makers and academics in Korea have criticised the informality of the chonsei practice compared to the Western system, while others advocate its role and meanings. As such, the chonsei market is vulnerable to fluctuation due to government intervention towards housing supply policy. Whilst the article has not explored its influence and status in the housing market, the findings show that it has contributed to not only the urban development pattern but also ordinary lives, which means that it should be better understood within its own contexts beyond the framework of Euro-American knowledge.

To conclude, although the higher ratio of ownership could be perceived as the ideal to achieve, the survival of chonsei means that such an informal system can fill the gap between the ideal and the actual market operation, serving those who are not eligible to secure formal own- ership from the government scheme. It would have not been possible that large-scale urban developments have spread over wider population due to the private sectorled development of high valued high-rise apartments. In this way, large urban high-rise developments based on the formal structure and informal practices have continued over the last half-century, which has transformed its physical and socio-spatial structure in Korean society and has contributed to Seoul and Gangnam becoming globalised. Therefore, the role and influence of informal system need to be better appreciated within the broad structure in the development process.

\section{Acknowledgments}

Many of the contents in this article have been extracted from the author's PhD thesis and it has been re-written under a new theoretical framework. Statistical data was obtained from the national Statistics Korea (KOSIS) if not specified in the article. The author is grateful to the two anonymous reviewers that brought greater clarity to the article.

\section{Conflict of Interests}

The author declares no conflict of interests.

\section{References}

Ambrose, B. W., \& Kim, S. (2003). Modelling the Korean chonsei lease contract. Real Estate Economics, 31(1), 53-74.

Baxter, R., \& Lees, L. (2009). The rebirth of high-rise living in London: Towards a sustainable, inclusive, and liveable urban form. In R. Imrie, L. Lees, \& M. Raco (Eds.), Regenerating London: Governance, sustainability and community in a global city (pp. 151-172). Oxon: Routledge.

Cammack, P. (2012). The G20, the crisis, and the rise of global developmental liberalism. Third World Quarterly, 33(1), 1-16.

Cha, J., You, H., \& Lee, J. (2004). Historical transition of residential differentiation in Seoul. Seoul: Baiksan Publishing House.

Chen, Y., \& Li, W. (2012). Neoliberalism, the developmental state, and housing policy in Taiwan. In B. Park, R. Hill, \& A. Saito (Eds.), Locating neoliberalism in East Asia (pp. 196-224). Chichester: Wiley-Blackwell.

Cho, J. (1988). An asset based theory of housing choice under credit constraints: The case of Korea (Unpublished Doctoral dissertation). Massachusetts Institute of Technology, Cambridge, USA.

Choi, C., \& Ji, K. (2007). Modeling chonsei and monthly rent structure with mortgage lending and tenant's asset constraint. Journal of Korea Planners Association, 42(3), 215-226.

Clammer, J. (2003). Globalisation, class, consumption and civil society in South-East Asian cities. Urban 
Studies, 40(2), 403-419.

Colomb, C. (2007). Unpacking new Labour's 'Urban Renaissance' agenda: Towards a socially sustainable reurbanization of British cities? Planning, Practice \& Research, 22(1), 1-24.

Featherstone, M., \& Venn, C. (2006). Problematising global knowledge and the new encyclopaedia project. Theory, Culture and Society, 23(1), 1-20.

Forrest, R. (2003). Some reflections on the housing question. In R. Forrest \& J. Lee (Eds.), Housing and social change: East-West perspectives (pp. 1-19). London: Routledge.

Forrest, R., Lee, J., \& Wah, C. K. (2000). Editors' introduction: Focus on housing in South-East Asia. Housing Studies, 15(1), 7-10.

Friedman, J. (1995). Where we stand now: A decade of world city research. In P. Knox \& P. Taylor (Eds.), World cities in a world system (pp. 21-47). Cambridge: Cambridge University Press.

Gelézeau, V. (2007). The republic of apartments. Seoul: Humanitas.

Ha, S. (2006). Housing policy. Seoul: Pakyoungsa.

$\mathrm{Ha}$, S. (2010). Housing crises and policy transformations in South Korea. International Journal of Housing Policy, 10(3), 255-272.

Harvey, D. (1989). From managerialism to entrepreneurialism: The transformation in urban governance in late capitalism. Geografiska Annaler-Series B, Human Geography, 71(1), 3-17.

Hirayama, Y. (2005). Running hot and cold in the urban home-ownership market: The experience of Japan's major cities. Journal of Housing and the Built Environment, 20(1), 1-20.

Holliday, I. (2000). Productivist welfare capitalism: Social policy in East Asia. Political Studies, 48(4), 706-723.

Huat, C. B. (2003). Maintaining housing values under the condition of universal home ownership. Housing Studies, 18(5), 765-780.

Jeon, N., Son, S., Yang, S., \& Hong, H. (2008). Sociological history of housing in Korea. Paju: Dolbegae.

Kim, J., \& Choe, S. (1997). Seoul: The making of a metropolis. Chichester: John Wiley \& Sons.

Kim, K. (2001). History of spatial transformation of Seoul in the 20th century. Seoul: The Seoul Institute.

Kim, K. (2010). Indicators for the transformation of Seoul: Major statistics and trend. Seoul: The Seoul Institute.

Kwak, Y. (1966). The law of reality. Seoul: Pakyoungsa.

Land and Housing Institute. (1990). Structural forms of apartment buildings. Daejoen: Land and Housing Institute.

Le Corbusier. (1960). Creation is a patient search. New York, NY: Frederick Praeger.

Lee, H. (2007). Dramatic growth of 60 years: Construction industry as an engine of the economic growth. The Construction Business Journal, 2007(December), 36-39. Retrieved from http://www.auric.or.kr/User/ Rdoc/DocCmag.aspx?returnVal=CMAG\&dn $=168342$ \#.XY-1DUZKiUk
Lee, J. (1995). A study on the expressions of the 'modernity' in the medium-rise multi-family housing in 1960. Journal of Architectural Institute of Korea, 11(6), 23-32.

Lee, J. (2014). The role and operation of the International Urban Development Cooperation Center. Korea Journal of Construction Engineering and Management, 15(2), 10-14.

Lee, S. (1985). Chonsei system for housing. Seoul: Gyoungyeong Munwhawon.

Lee, S. (1986). A study of the residential differentiation in Seoul (Unpublished Doctoral dissertation). Ewha Woman's University, Seoul, South Korea.

Lee, C., Lee, J., \& Yim, C. (2003). A revenue-sharing model of residential redevelopment projects: The case of the Hapdong redevelopment scheme in Seoul, Korea. Urban Studies, 40(11), 2223-2237.

Lim, S. (1970). Around planning of Hangang Mansion apartment. Seoul: Korea Housing Research Institute.

Lim, S. (2005). A half-century of housing policy. Seoul: Gimundang.

Paling, W. (2012). Planning a future for Phnom Penh: Mega projects, aid Dependence and disjointed governance. Urban Studies, 49(13), 2889-2912.

Park, S. (2000). Origins of chonsei system and prospects for chonsei market. Jutaek, 64, 36-46.

Park, B., Hill, R., \& Saito, A. (2012). Locating neoliberalism in East Asia. Chichester: Wiley-Blackwell.

Park, C., \& Jeon, B. (2002). The socio-economical background and characteristics of plan of urban traditional housing in Seoul of the 1930s. Journal of Architectural Institute of Korea: Planning Series, 18(7), 95-106.

Peck, J., \& Theodore, N. (2007). Variegated capitalism. Progress in Human Geography, 31(6), 731-772.

Percival, T., \& Waley, P. (2012). Articulating intra-Asian urbanism: The production of satellite cities in Phnom Penh. Urban Studies, 49(13), 2873-2888.

Perry, C. A. (1929). The neighborhood unit. In Committee on Regional Plan of New York and its Environs (Ed.), Neighborhood and community planning. Regional survey VII (pp. 20-140). New York, NY: Regional Plan of New York and its Environs.

Robinson, J. (2002). Global and world cities: A view from off the map. International Journal of Urban and Regional Research, 26(3), 531-554.

Robinson, J. (2006). Inventions and interventions: Transforming cities. Urban Studies, 43(2), 251-258.

Ronald, R., \& Hirayama, Y. (2006). Housing commodities, context and meaning: Transformations in Japan's urban condominium sector. Urban Studies, 43(13), 2467-2483.

Ronald, R., \& Lee, H. (2012). Housing policy socialization and de-commodification in South Korea. Journal of Housing and the Built Environment, 27(2), 111-131.

Roy, A. (2009). The 21st century metropolis: New geographies of theory. Regional Studies, 43(6), 819-830.

Roy, A. (2011). Urbanisms, worlding practice and the the- 
ory of planning. Planning Theory, 10(1), 6-15.

Ryu, Y. (2004). The (re)production of urban housing space and housing policies in South Korea in the 1980s and 1990s: From institutional perspectives. Journal of the Korean Geographical Society, 39(5), 768-785.

Shatkin, G. (2008). The city and the bottom line: Urban megaprojects and the privatization of planning in Southeast Asia. Environment and Planning A, 40(2), 383-401.

Shatkin, G. (2011). Coping with actually existing urbanisms: The real politics of planning in the global era. Planning Theory, 10(1), 79-87.

Son, J. (1986). Urban housing problems and solutions under the Japanese colonial period. Urban Management Studies, 1, 123-196.

Son, J. (1996a). A study of urbanisation process under the Japanese colonial period. Seoul: Iljisa.

Son, J. (1996b). A study of urban social phenomena under the Japanese colonial period. Seoul: Iljisa.
Son, J. (2003). The story of urban planning in Seoul 2. Seoul: Hanul.

Song, I. (1990). A study on the types of urban traditional housing in Seoul from 1930 to 1960 (Unpublished Doctoral dissertation). Seoul National University, Seoul, South Korea.

Tang, W. S. (2017). Beyond gentrification: Hegemonic redevelopment in Hong Kong. International Journal of Urban and Regional Research, 41(3), 487-499.

The Seoul Institute. (2014). Exporting the Seoul policy model to overseas. Seoul: The Seoul Institute.

Wah, C. K. (2000). Prosperity or inequality: Deconstructing the myth of home ownership in Hong Kong. Housing Studies, 15(1), 29-44.

Watson, V. (2009). Seeing from the South: Refocusing urban planning on the globe's central urban issues. Urban Studies, 46(11), 2259-2275.

Yang, O. (1991). Transition of population and residences in Seoul: 1394-1945 (Unpublished Doctoral dissertation). Ewha Woman's University, Seoul, South Korea.

\section{About the Author}

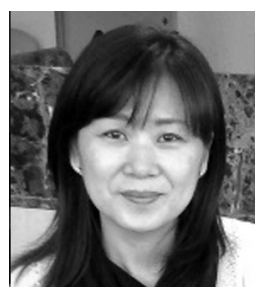

Jinhee Park holds a PhD in Urban Studies and Planning at the University of Sheffield. She has experience working with academic and governmental institutes in Korea and the UK. Her current research focuses on large urban developments in capitalism with aspects of the role of real estate developers, cultural and institutional economy, and transnational developments in which they transform and shape urban life socially, spatially, economically, politically and culturally. 